Original Research

\title{
How Might Changing Climate Limit Cyanobacteria Growth in Shallow Prairie Lakes? An Empirical Space-For-Time Evaluation of the Potential Role of Increasing Sulfate
}

Susan M. Joshi ${ }^{\dagger}$, Leland J. Jackson ${ }^{\dagger, *}$

Ecology and Evolutionary Biology Research Cluster, Department of Biological Sciences, University of Calgary, 2500 University Drive NW, Calgary Alberta, Canada, T2N 1N4; E-Mails: susan joshi@outlook.com; ljackson@ucalgary.ca

+ These authors contributed equally to this work.

* Correspondence: Leland J. Jackson; E-Mail: ljackson@ucalgary.ca

Academic Editor: Lee C. Bowling

Special Issue: Cyanobacterial Blooms

Adv Environ Eng Res

2022, volume 3, issue 1

doi:10.21926/aeer.2201007
Received: November 20, 2021

Accepted: February 05, 2022

Published: February 15, 2022

\begin{abstract}
Cyanobacteria blooms alter aquatic ecosystems and occur frequently in shallow prairie lakes, which are predicted to increase in salinity as the regional climate becomes hotter and drier. However, flat landscapes that experience depression bottom salinity with high concentrations of sulfate in addition to sodium and chloride, may mitigate nutrient increases or even inhibit cyanobacteria growth. Cyanobacteria can dominate shallow lakes with low N:P ratios because many cyanobacteria species fix dissolved $\mathrm{N}_{2}$, whether due to in-lake denitrification or exchange with the atmosphere, a process that requires molybdenum as an enzyme cofactor. Sulfate can compete with molybdate at cellular uptake sites, potentially limiting the competitive advantage of cyanobacteria. We studied 25 lakes located in a relatively limited geographic region of southern Alberta (Canada) and used a space-for-time analysis to model scenarios of increased sulfate concentrations under changing climate. Monthly, we measured nitrogen, phosphorus, sulfate, molybdenum, and cyanobacterial pigments and used mixed
\end{abstract}


effects models to identify empirical relationships. Sulfate drives conductivity in the region and we found that most saline lakes we sampled are turbid lakes with high nutrients and high cyanobacteria biomass. In addition to phosphorus, molybdenum predicted cyanobacterial pigments in the top two models, showing a positive relationship with cyanobacterial biomass. We also found a negative relationship between sulfate concentration and cyanobacteria pigments, which suggests that as lakes get saltier, even with increased nutrients, there may not be an incremental increase in cyanobacteria biomass. Our results therefore suggest that competition between sulfate and molybdate may limit future cyanobacteria growth in shallow lakes and that with a warmer and drier climate it may not be inevitable that shallow lakes will continue to be dominated by cyanobacterial blooms, a hypothesis that could be tested directly via experimentation.

\section{Keywords}

Cyanobacteria; nitrogen fixation; salinization; sulfate; shallow lakes; alternate regimes

\section{Introduction}

Toxic cyanobacteria are a global public health concern $[1,2]$ and are increasingly found in shallow lakes [3-6]. Many shallow prairie lakes are endorheic basins that are expected to increase in salinity due to regional climate becoming hotter and drier, which would decrease water inputs, increase water evaporation and decrease water levels, and therefore increase salt concentrations [7-9]. Salts, such as sulfate, accumulate from weathering of surrounding soil and bedrock. Sulfate concentrations in shallow lakes may increase [10] as prairie climate becomes hotter (increases of $3-5^{\circ} \mathrm{C}$ annual mean temperatures) and drier (decreases of $5-10 \%$ in precipitation) by the 2050s [9]. In agricultural regions, shallow prairie lakes also have increased nitrogen $(N)$ and phosphorus $(P)$ due to fertilizer used on surrounding croplands over the past $60-70$ years $[11,12]$. The role of macronutrients and their supply ratios in generating cyanobacterial blooms has been well studied $[13,14]$, but the importance of micronutrients, including enzyme co-factors, is much less clear, particularly in shallow lakes. However, increases in salinity may actually inhibit cyanobacteria growth [15].

Phosphorus has been argued to be the major driver of cyanobacteria growth $[16,17]$ with the role of $\mathrm{N}$ more contentious $[18,19]$. Phytoplankton biomass often correlates with total $\mathrm{P}[20]$, yet a low N:P ratio can shift the phytoplankton to cyanobacterial dominance [21] because cyanobacterial $\mathrm{N}$-fixation can reduce $\mathrm{N}$-limitation [22]. However, if $\mathrm{N}$-fixation alone provided enough $\mathrm{N}$, primary productivity should never be $\mathrm{N}$-limited [23]. Low productivity biomes, such as open oceans, are in contact with the $\mathrm{N}_{2}$-rich atmosphere yet make it clear that $\mathrm{N}$-limitation exists even with abundant $\mathrm{N}_{2}[24]$.

During times of $\mathrm{N}$-limitation, $\mathrm{N}$-fixation provides a competitive advantage to $\mathrm{N}$-fixing cyanobacteria provided there are sufficient micronutrients, such as molybdenum (Mo) or iron (Fe) that are enzyme cofactors of nitrogenase [25]. Mo is a trace metal predominantly found in oxic water as molybdate $\left(\mathrm{MoO}_{4}{ }^{2-}\right)$ [26] and derives from geologic weathering [27]. Typically, $\mathrm{MoO}_{4}{ }^{2-}$ concentrations are relatively conserved [28]. Cyanobacteria take up $\mathrm{MoO}_{4}{ }^{2-}$ through specific sites 
prior to synthesizing nitrogenase [26]. However, in saline water, sulfate $\left(\mathrm{SO}_{4}{ }^{2-}\right)$ can outcompete $\mathrm{MoO}_{4}{ }^{2-}$ at uptake sites because the ions share a similar charge-to-mass ratio and stereochemistry [26]. Although low Mo availability has been shown to limit cyanobacteria growth in saline coastal systems [29], it remains unknown whether this applies to all aquatic systems or whether a threshold exists where $\mathrm{SO}_{4}{ }^{2-}$ restricts the availability of $\mathrm{MoO}_{4}{ }^{2-}$ enough to limit cyanobacteria growth in freshwater systems, including shallow prairie lakes.

The goal of this study was to investigate implications of changing climate on future cyanobacteria growth in shallow prairie lakes. We employed a space-for-time analysis with 25 southern Alberta shallow lakes that span a large range in salinity, yet are within a relatively limited geographical area. We used general linear mixed effects models to test the hypothesis that $\mathrm{MoO}_{4}{ }^{2-}$ availability limits cyanobacteria growth and therefore late summer cyanobacteria biomass. We also looked for empirical evidence of a threshold ratio where $\mathrm{SO}_{4}{ }^{2-}$ outcompetes $\mathrm{MoO}_{4}{ }^{2-}$ and inhibits cyanobacteria growth.

\section{Materials and Methods}

\subsection{Study Area}

Lakes sampled were 60 to 160 kilometers east of Calgary, Alberta, in the semi-arid prairie pothole region characterized by mixed fescue grasses, black and brown chernozemic and solonetzic soils where there are natural saline conditions [30]. The dominant salts are sodium and magnesium sulfates, and salts primarily derive from bedrock and glacial till [31]. Groundwater seepages that concentrate salts are primarily local, rather than regional, and primarily depression-bottom salinity [31]. A variety of crops, such as spring and winter (non-durum) wheat and canola dominate the land cover [32] in addition to livestock operations. In 2011, $88 \%$ of total cropland in the local area had commercial fertilizer applied to it [33]. Livestock manure is typically redistributed on fields [33].

\subsection{Lake Selection}

Sampled lakes (Figure 1) were purposely chosen to include a salinity gradient, which was estimated from conductivity measured in the field before sampling began. Eleven lakes had been previously sampled [34,35], which provided a known range of salinity and history of cyanobacteria blooms for those lakes. Table 1 summarizes selected physical and chemical attributes of all study lakes. 


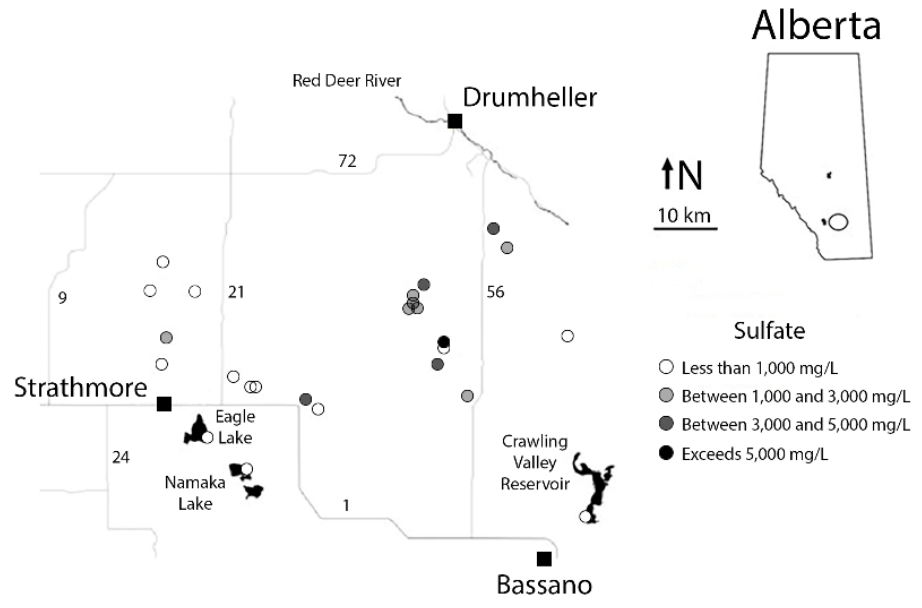

Figure 1 A map of 25 shallow prairie lakes sampled for an east-west gradient of sulfate. Points represent sampling locations on lakes and grey scale shows four binned categories indicating sulfate concentrations from one sample taken in August 2016. Inset map of Alberta shows the two major cities, Calgary and Edmonton and the circle shows the study area shown in the larger map. Map tiles by Stamen Design, under CC BY 3.0. Data by Open Street Map under CC. License found at:

https://creativecommons.org/licenses/by/3.0/legalcode. Lake data and place names added by SMJ and LJJ. 
Table 1 Selected characteristics of 25 shallow prairie lakes sampled to determine relationships between cyanobacteria pigments, sulfate and molybdate across a broad salinity gradient. Values are the mean +/- SEM of three samples taken in August 2016. Lake location and selected biological and chemical characteristics of 25 shallow prairie lakes sampled in Alberta. ${ }^{*} Z_{\max }$ was taken from previous studies [34, 35].

\begin{tabular}{|c|c|c|c|c|c|c|c|c|}
\hline Lake & Longitude & Latitude & $\begin{array}{l}\text { Surface Area } \\
\text { (ha) }\end{array}$ & $\begin{array}{l}Z_{\max }{ }^{*} \\
(m)\end{array}$ & $\begin{array}{l}\text { Temp. } \\
\left({ }^{\circ} \mathrm{C}\right)\end{array}$ & $\begin{array}{l}\text { Conductivity } \\
(\mu \mathrm{S} / \mathrm{cm})\end{array}$ & $\mathrm{pH}$ & Turbidity (NTU) \\
\hline Two Bar & 51.2713 & -112.57 & 42.7 & - & 18.8 & $4,474(+/-24)$ & 9.14 & $9(+/-1.86)$ \\
\hline Barnett & 51.069 & -113.23 & 29 & 2.1 & 18.1 & $2,272(+/-6)$ & 9.04 & $3(+/-0.03)$ \\
\hline Black & 51.0955 & -112.73 & 9.9 & - & 19.7 & $6,053(+/-48)$ & 8.66 & $15(+/-4.09)$ \\
\hline Bow & 51.1829 & -112.79 & 3.2 & - & 19.7 & $6,046(+/-37)$ & 9.33 & $164(+/-21.09)$ \\
\hline Brush & 51.2433 & -113.4 & 42.4 & 0.7 & 18.7 & $18,873(+/-122)$ & 10.2 & $146(+/-1.86)$ \\
\hline Carlson & 51.2093 & -113.33 & 11.6 & 1.7 & 17.6 & $548(+/-72)$ & 10.3 & $4(+/-2.7)$ \\
\hline Crawling Valley & 50.8629 & -112.38 & 2,345 & 16 & 22.4 & $344(+/-6)$ & 9.44 & $2(+/-1.04)$ \\
\hline Crow & 51.1215 & -112.7 & 9.9 & - & 17.3 & $3,473(+/-27)$ & 8.68 & $20(+/-7.14)$ \\
\hline Dawson & 51.1346 & -113.4 & 32.8 & 1.7 & 22.9 & $7,275(+/-210)$ & 9.72 & $8(+/-0.63)$ \\
\hline Dead & 51.1291 & -112.7 & 6.6 & - & 20.7 & $13,397(+/-40)$ & 9.09 & $120(+/-5.58)$ \\
\hline Dog & 51.2115 & -112.77 & 6.5 & - & 21.3 & $6,371(+/-160)$ & 9.03 & $565(+/-406.63)$ \\
\hline Eagle & 50.9848 & -113.3 & 1,137 & 4.9 & 18.3 & $1,373(+/-117)$ & 9.07 & $13(+/-2.18)$ \\
\hline East & 51.0601 & -113.19 & 3.46 & 1.4 & 19.6 & $1,227(+/-3)$ & 8.77 & $34(+/-19.54)$ \\
\hline Foot & 51.0473 & -112.67 & 1,134 & - & 16.4 & $3,680(+/-22)$ & 9.41 & $106(+/-10.71)$ \\
\hline Fred & 51.028 & -113.03 & 21.5 & 1.1 & 19.4 & $2,227(+/-38)$ & 9.78 & $25(+/-8.71)$ \\
\hline Goat & 51.2096 & -113.43 & 44 & 0.4 & 19.5 & $7,818(+/-78)$ & 9.76 & $161(+/-11.86)$ \\
\hline Greg & 51.1838 & -112.81 & 0.9 & - & 20.4 & $4,783(+/-23)$ & 9.34 & $25(+/-1.09)$ \\
\hline Horse & 51.0427 & -113.06 & 118 & 1 & 18.4 & $9,038(+/-22)$ & 9.53 & $16(+/-0.4)$ \\
\hline Long & 51.0592 & -113.19 & 9.8 & 1.6 & 19.3 & $1,357(+/-105)$ & 8.97 & $67(+/-45.34)$ \\
\hline Mushroom & 51.0956 & -113.41 & 16.6 & 1.3 & 17.7 & $636(+/-14)$ & 10.1 & $3(+/-0.57)$ \\
\hline Namaka & 50.9351 & -113.2 & 514 & - & 18.7 & $1,700(+/-114)$ & 10.1 & $7(+/-0.4)$ \\
\hline Song & 51.2016 & -112.8 & 5.7 & - & 19.9 & $5,573(+/-12)$ & 9.88 & $7(+/-0.41)$ \\
\hline Seiu & 51.1408 & -112.41 & 308 & - & 21 & $968(+/-18)$ & 9.67 & $46(+/-7.09)$ \\
\hline
\end{tabular}


Adv Environ Eng Res 2022; 3(1), doi:10.21926/aeer.2201007

\begin{tabular}{|c|c|c|c|c|c|c|c|}
\hline $\begin{array}{l}\text { West } \\
\text { Whey }\end{array}$ & $\begin{array}{l}51.0598 \\
51.3 \\
\end{array}$ & $\begin{array}{l}-113.19 \\
-112.61 \\
\end{array}$ & & $\begin{array}{l}19.5 \\
19.2 \\
\end{array}$ & $\begin{array}{l}1,092(+/-8) \\
8,882(+/-35) \\
\end{array}$ & $\begin{array}{l}8.4 \\
9.94 \\
\end{array}$ & $\begin{array}{l}(+/-385.29) \\
(+/-1.78)\end{array}$ \\
\hline \multicolumn{8}{|c|}{ Table 1, Con't } \\
\hline Lake & $\begin{array}{l}\text { Total Nitrogen } \\
\left(\mathrm{mg} \cdot \mathrm{L}^{-1}\right)\end{array}$ & $\begin{array}{l}\text { Total Phosphorus } \\
\left(\mathrm{mg} \cdot \mathrm{L}^{-1}\right)\end{array}$ & $\begin{array}{l}\text { TN: } \\
\text { TP }\end{array}$ & $\begin{array}{l}\text { Sulfate } \\
\left(\mathrm{mg} \cdot \mathrm{L}^{-1}\right)\end{array}$ & $\begin{array}{l}\text { Molybdenum } \\
\left(\mathrm{mg} \cdot \mathrm{L}^{-1}\right)\end{array}$ & $\begin{array}{l}\text { Chlorophyll-a } \\
\left(\mathrm{mg} \cdot \mathrm{L}^{-1}\right)\end{array}$ & $\begin{array}{l}\text { Cyanopigment } \\
\left(\mathrm{mg} \cdot \mathrm{L}^{-1}\right)\end{array}$ \\
\hline Two Bar & $7,898(+/-83)$ & $1,920(+/-527)$ & 4 & $1,359(+/-32)$ & $1(+/-0.4)$ & $6(+/-0.48)$ & $0(+/-0)$ \\
\hline Barnett & $1,723(+/-58)$ & $38(+/-13)$ & 50 & 755 (+/-39) & $2(+/-0.3)$ & $3(+/-0.33)$ & $0(+/-0.14)$ \\
\hline Black & $6,804(+/-66)$ & $1,396(+/-212)$ & 5 & $3,092(+/-164)$ & $2(+/-0.2)$ & $11(+/-6.48)$ & $1(+/-0.88)$ \\
\hline Bow & $13,360(+/-652)$ & $635(+/-79)$ & 21 & $2,919(+/-59)$ & $2(+/-0.2)$ & $383(+/-60.65)$ & $29(+/-12.22)$ \\
\hline Brush & $15,710(+/-917)$ & $7,673(+/-934)$ & 2 & $23(+/-11)$ & $3(+/-0.2)$ & $257(+/-21.74)$ & 60 (+/-12.29) \\
\hline Carlson & $1,477(+/-456)$ & $140(+/-144)$ & 17 & $78(+/-3)$ & $2(+/-0.2)$ & $10(+/-16.18)$ & $1(+/-2.37)$ \\
\hline Crawling Valley & $529(+/-159)$ & $30(+/-5)$ & 17 & $74(+/-3)$ & $1(+/-0.2)$ & $1(+/-0.65)$ & $0(+/-0.01)$ \\
\hline Crow & $4,236(+/-95)$ & $145(+/-96)$ & 37 & $1,693(+/-22)$ & $16(+/-18.6)$ & $2(+/-1.2)$ & $0(+/-0)$ \\
\hline Dawson & $4,355(+/-79)$ & $936(+/-154)$ & 5 & $2,902(+/-89)$ & $5(+/-0.3)$ & $4(+/-0.84)$ & $1(+/-1.62)$ \\
\hline Dead & $12,253(+/-102)$ & $709(+/-71)$ & 17 & $8,786(+/-242)$ & $2(+/-0.3)$ & $108(+/-5.52)$ & $5(+/-4.94)$ \\
\hline Dog & $10,203(+/-9125)$ & $1,095(+/-1199)$ & 11 & $3,175(+/-126)$ & $8(+/-9.1)$ & $2,121(+/-2373.99)$ & $323(+/-407.36)$ \\
\hline Eagle & $5,098(+/-3484)$ & $159(+/-37)$ & 30 & $331(+/-17)$ & $4(+/-0.4)$ & $38(+/-61.99)$ & $6(+/-10.08)$ \\
\hline East & $2,184(+/-137)$ & $572(+/-60)$ & 4 & $395(+/-50)$ & $3(+/-0.4)$ & $70(+/-19.71)$ & $8(+/-3.52)$ \\
\hline Foot & $3,007(+/-98)$ & $1,850(+/-525)$ & 2 & $1,088(+/-41)$ & $10(+/-0.9)$ & $6(+/-0.71)$ & $1(+/-1.47)$ \\
\hline Fred & $3,215(+/-80)$ & $21(+/-9)$ & 170 & $860(+/-6)$ & $2(+/-0.2)$ & $4(+/-0.88)$ & $0(+/-0.4)$ \\
\hline Goat & $4,611(+/-513)$ & $3,014(+/-707)$ & 2 & $959(+/-5)$ & $97(+/-1.9)$ & $4(+/-0.63)$ & $1(+/-0.77)$ \\
\hline Greg & $5,606(+/-121)$ & $573(+/-183)$ & 10 & $2,392(+/-58)$ & $3(+/-0.7)$ & $27(+/-3.08)$ & $1(+/-1.01)$ \\
\hline Horse & $5,607(+/-92)$ & $296(+/-145)$ & 23 & $4,934(+/-105)$ & $6(+/-0.3)$ & $10(+/-0.79)$ & $0(+/-0.12)$ \\
\hline Long & $2,287(+/-102)$ & $548(+/-109)$ & 4 & $456(+/-69)$ & $3(+/-0.2)$ & $133(+/-126.64)$ & $12(+/-10.58)$ \\
\hline Mushroom & $2,200(+/-16)$ & $231(+/-88)$ & 11 & $82(+/-7)$ & $2(+/-0.1)$ & $3(+/-0.17)$ & $0(+/-0.48)$ \\
\hline Namaka & $2,187(+/-124)$ & $111(+/-14)$ & 20 & $447(+/-5)$ & $5(+/-0.1)$ & $4(+/-2.74)$ & $0(+/-0.67)$ \\
\hline Song & $5,432(+/-52)$ & $144(+/-32)$ & 39 & $1,852(+/-90)$ & $1(+/-0.2)$ & $8(+/-0.41)$ & $0(+/-0.35)$ \\
\hline Seiu & $3,380(+/-56)$ & $717(+/-371)$ & 6 & $143(+/-23)$ & $2(+/-0.1)$ & $36(+/-4.32)$ & $4(+/-2.18)$ \\
\hline West & $2,518(+/-1097)$ & $971(+/-814)$ & 3 & $309(+/-10)$ & $3(+/-1.2)$ & $353(+/-541.38)$ & $39(+/-49.77)$ \\
\hline Whey & $8,077(+/-139)$ & $1,000(+/-277)$ & 9 & $3,295(+/-142)$ & $15(+/-0.3)$ & $98(+/-15.14)$ & $1(+/-1.07)$ \\
\hline
\end{tabular}




\subsection{Lake Sampling}

Twenty-five lakes were sampled four times (once each in June, July, August and September) between June 13 and September 6, 2016. At each lake, three samples were taken in acid-bathed (minimum 3 hours in $25 \% \mathrm{HCl}$ and triple DDW rinsed) $1 \mathrm{~L}$ Nalgene bottles by wading 1 to 4 meters from the shore and by using a bottle holder to avoid debris suspended from wading. At each site, the bottle was triple-rinsed with lake water and then the sample was taken from immediately under the water surface, then stored in a dark cooler on ice for transport back to the lab. The depth at the sampling site never exceeded $1.5 \mathrm{~m}$ and occasionally was less than $30 \mathrm{~cm}$. The samples were purposely taken to include a "worst-case" scenario by visually inspecting the lake's surface for suspected cyanobacteria abundance, and sampling in the bloom, if seen. The three sampling sites were at least $30 \mathrm{~m}$ apart, if possible. Turbidity was measured with a $\mathrm{HACH}$ Portable turbidity meter (model 2100Q). Conductivity and temperature were measured with a ThermoScientific Orion Star (model A325) $\mathrm{pH} /$ conductivity portable multi-parameter meter. The $\mathrm{pH}$ of each sample was measured in the lab using a Mettler Toledo, FiveEasy Plus (model FP20) pH meter.

\subsection{Lab Methods}

\subsubsection{Ion and Nutrient Analysis of Lake Water}

Soluble reactive phosphorus, ammonia, nitrate + nitrite, sulfate and molybdenum samples were filtered using Pall Corporation Life Sciences GN Metricel Grid $0.45 \mu \mathrm{m}$ filters within 7 hours of collection and stored in sterile $50 \mathrm{~mL}$ polypropylene conical tubes overnight at $4^{\circ} \mathrm{C}$. All nutrient samples were analyzed within 24 hours of collection, except where noted.

Total nitrogen was measured on a Shimadzu TOC-L Combustion Analyzer with TNM-L module with a Shimadzu ASI-L auto sampler with dilution, if necessary. Nitrate and nitrite were measured using ion chromatography on a Metrohm 940 Professional IC Vario equipped with a Metrohm 858 Professional sample processor.

Ammonia, sulfate, total phosphorus and soluble reactive phosphorus were measured on a WestCo Scientific Instruments Inc. Smart Chem (Model 170) discrete analyzer. Ammonia was measured with the Berthelot reaction following Method AMM-001-A [36]. Total phosphorus and soluble reactive phosphorus were measured with the molybdate blue method [37] using Method PHO-004-A [38]. Sulfate was measured using Method SUL-002-A [39]. Samples were auto-diluted by the Smart Chem or manually diluted beforehand and auto-diluted when sulfate levels were above the calibration curve.

Molybdenum samples were filtered through a Pall Corporation Life Sciences GN Metricel Grid $0.45 \mu \mathrm{m}$ and refrigerated at $4^{\circ} \mathrm{C}$ for a maximum of 5 months. At analysis, samples were acidified to $1 \% \mathrm{HNO}_{3}{ }^{-}$to prevent precipitation and measured using an Agilent Technologies 8800 ICP-MS Triple Quad with an ASX-500 Series ICP-MS auto sampler. Molybdenum 95 and 98 were measured and the molybdenum 98 isotope measurements were used. Typically, triplicate measurements were made from a single vial for a given sample. In five lakes (Brush, Black, Whey, Horse and Dawson), the salt concentrations created matrix effects and in these instances, the method of standard addition was performed to obtain an accurate measurement. Indium was used as the internal standard to correct for any signal drift during analysis. Total molybdenum (Mo) was measured because molybdenum is 
predominantly found in oxic waters as the thermodynamically stable oxyanion molybdate [26], which is the Mo form taken up by cyanobacteria.

\subsubsection{Pigment Analyses}

Chlorophyll- $a$ and accessory pigment measurements were performed on phytoplankton collected on $47 \mathrm{~mm}$ VWR glass microfiber filters (model 696; $1.2 \mu \mathrm{m}$ pore size) under low light and then frozen in aluminum packets at $-20^{\circ} \mathrm{C}$ for up to 5 months for later analyses. Filters were first freeze-dried in the dark over 48 hours in a Labconco, FreeZone 6 freeze drier to remove remaining water, then the pigments were extracted under low light by placing the filter in $10 \mathrm{~mL}$ of $98 \%$ ethanol, vortexing and letting the samples extract for 24 hours. Samples were then centrifuged and measured in small batches using a Molecular Devices SpectraMax M2 plate reader at 300 wavelengths from $400-700 \mathrm{~nm}$. The data were then analyzed using pigment-based chemotaxonomy and a Gaussian peak function, which predicts the range of pigments present in the sample $[40,41]$. The software estimates pigments from cyanobacteria, diatoms, dinoflagellates and green algae. We used chlorophyll- $a$, plus myxoxanthin, canthaxanthin and echinenone, the latter three which are specific to cyanobacteria, to create a parameter called "cyanopigment" by selecting the highest concentration out of the three pigments from each sample. Adding the three cyanobacteria pigments together would over-estimate the concentrations because all three of the pigments can occur in the same cyanobacterial species [42]. However, to use only one pigment would underestimate the cyanobacteria biomass because not every species produces all three pigments. Use of the highest pigment still underestimates the total concentration if two species in a sample contain different accessory pigments and we only use the highest accessory pigment to quantify the sample.

\subsection{Statistical Analyses}

All analyses were performed with $\mathrm{R}$ version 3.3.2 [43], and RStudio version 1.0.136 [44], using the Ime4 [45], ImerTest [46] and effects [47] packages. General linear mixed effects models were analyzed with the Imer function in the Ime4 R package [45] and generalized linear mixed effects models were analyzed with the Ime4 function in the glmer package [48]. Stepwise regression was performed with the Ime4::drop1 function [45]. P-values were calculated with the Ime4::drop1 function using the Chi-squared test and with the ImerTest package using the Satterthwaite method. Figures were made with MS Excel, ggplot2 [49] and ggmap [50].

Cyanopigment was the dependent variable of three models: one with three extreme lakes removed (Ime), one with all lakes included (Ime) and one with the binomial family (gImm). For the two linear mixed effects models, lake and month were included as random effects. The random effect structure reflected the study design by allowing a random slope of month, within lake, with correlated intercept [51] and also calculated covariance. The assumptions of normality and homoscedasticity in the residuals were met by visually inspecting the residuals vs. fitted plot [52]. Only observations of cyanopigment above the detectable limits were included in the linear mixed effects models. To minimize the spread in the fixed effects' ranges and to reduce heterogeneity, sulfate was $\log _{10}$ transformed and the other fixed effects and the dependent variable were natural $\log (\ln )$ transformed. To test the effect of extreme values on the models, we ran the model with and without the values and report both models. In the first model, two lakes with extreme sulfate 
concentrations were removed, which lowered the range of sulfate from $13-17,324 \mathrm{mg} \cdot \mathrm{L}^{-1}$ to $13-$ $7,856 \mathrm{mg} \cdot \mathrm{L}^{-1}$ (mean: 1460, median: 854 ) and one lake with extreme molybdenum concentrations was also removed, which lowered the range from $0.4-132 \mu \mathrm{g} \cdot \mathrm{L}^{-1}$ to $0.4-38 \mu \mathrm{g} \cdot \mathrm{L}^{-1}$. Truncated data were included in the third model where cyanopigment presence/absence was coded with a categorical variable $(0 s, 1 s)$ to determine significant effects for detection and below detection. The binomial model was a generalized linear mixed effects model with the family as binomial and the link function as logit. This model included all lakes and tested the same fixed effects as the first model; however the interaction term was not included. In this model, lake was included as a random effect and month was included as a fixed effect. Month was not included as a random effect on its own because there were insufficient levels (five to six levels are recommended at minimum; [51]). Variables were scaled to account for covariance.

\section{Results}

\subsection{General Patterns of the Study Lakes}

The 25 shallow lakes sampled included broad ranges of conductivity, sulfate, total nitrogen and total phosphorus while in contrast, molybdenum varied less (Table 1). Conductivity had a relatively even and broad range (330.9-20,760 $\mu \mathrm{S} / \mathrm{cm}$ - Figure 2) as lakes were purposely selected to include a conductivity gradient. Sulfate encompassed three orders of magnitude $\left(13-17,324 \mathrm{mg} \cdot \mathrm{L}^{-1}-\right.$ Figure 2) with higher sulfate levels further east (Figure 1), except for the two large lakes farthest east (Seiu Lake and Crawling Valley). Brush Lake (Figure 2) had the highest conductivity (18.17-20.7 mS/cm) yet almost the lowest sulfate (13-93 $\mathrm{mg}^{\cdot \mathrm{L}^{-1}}$ ). Molybdenum concentrations varied less across the 25 lakes (median $3.0 \mu \mathrm{g} \cdot \mathrm{L}^{-1}$; range $0.4-132 \mu \mathrm{g} \cdot \mathrm{L}^{-1}$ ). Goat Lake had a maximum molybdenum concentration 2.5 times greater than the next highest lake $\left(132 \mu \mathrm{g} \cdot \mathrm{L}^{-1}\right.$ compared to $\left.37 \mu \mathrm{g} \cdot \mathrm{L}^{-1}\right)$, which accounts for the high range and mean. Every lake had detectable molybdenum concentrations. 

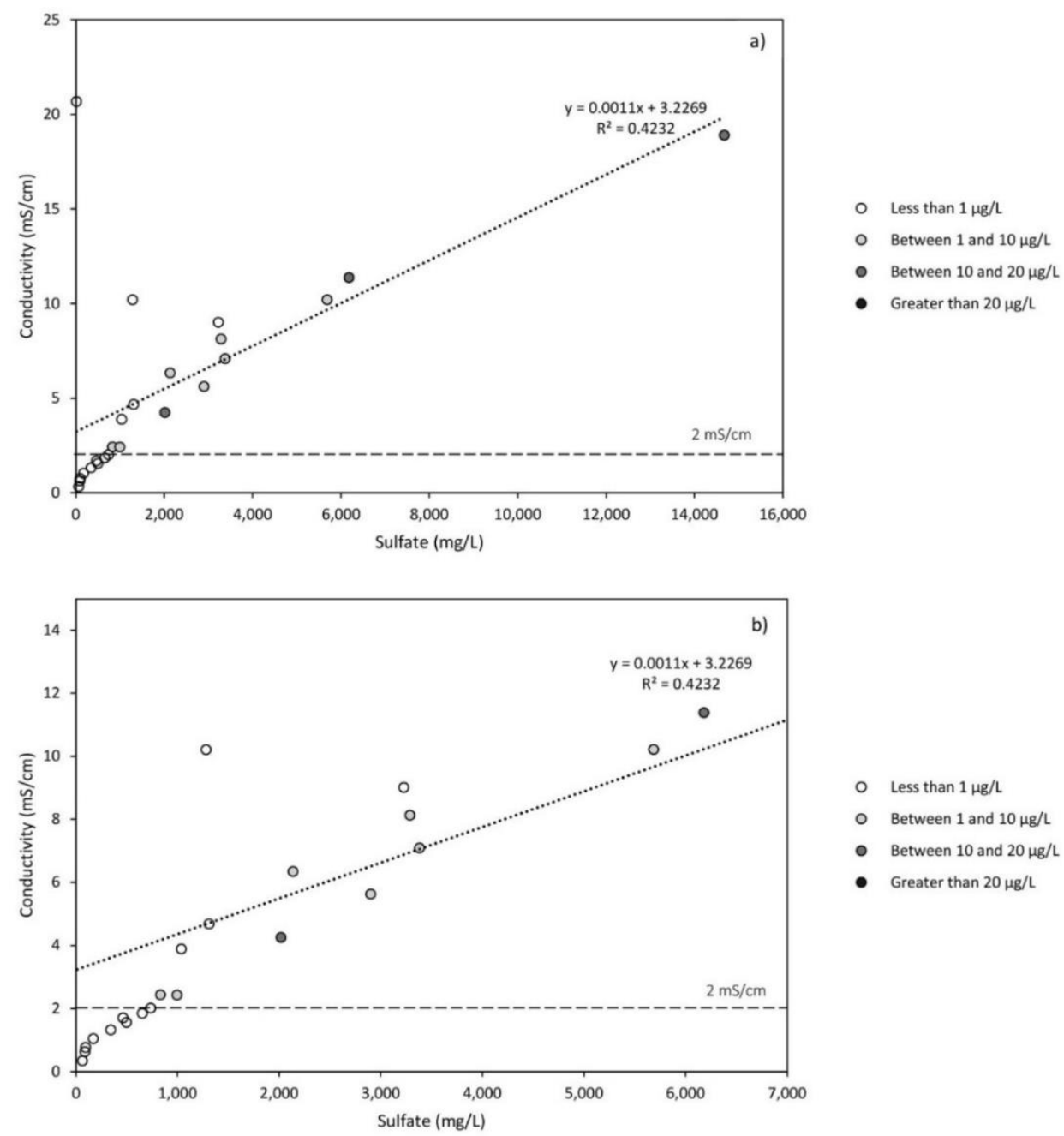

Figure 2 Relationship between conductivity $\left(\mathrm{mS} \cdot \mathrm{cm}^{-1}\right)$, sulfate $\left(\mathrm{mg} \cdot \mathrm{L}^{-1}\right)$ and cyanopigment $\left(\mu \mathrm{g} \cdot \mathrm{L}^{-1}\right.$ ) for 25 shallow prairie lakes sampled in July 2016 . Points represent the mean of three samples. The horizontal black dashed line represents $2 \mathrm{mS}$ $\mathrm{cm}^{-1}$, the approximate cut off between fresh and brackish water. The dotted line represents the regression line. The full range (a) and (b) details for conductivity $<14 \mathrm{mS}$ $\mathrm{cm}^{-1}$ and sulfate $<7,000 \mathrm{mg} \cdot \mathrm{L}^{-1}$ are shown.

Nutrient concentrations would classify lakes from oligotrophic to highly eutrophic [53], with some lakes having extremely high total nitrogen and total phosphorus concentrations. Total nitrogen ranged from 394-20,730 $\mu \mathrm{g} \cdot \mathrm{L}^{-1}$ (median 4,239 $\left.\mu \mathrm{g} \cdot \mathrm{L}^{-1}\right)$. Total phosphorus ranged from 20$12,032 \mu \mathrm{g} \cdot \mathrm{L}^{-1}$ (median $\left.551 \mu \mathrm{g} \cdot \mathrm{L}^{-1}\right)$. The TN:TP ratio ranged from 0.9 to 98.9 with a median of 8.4. Total nitrogen and conductivity also correlated (linear regression, $R^{2}=0.73, d f=23, p=0.03$ - Figure 3 ). High cyanobacterial pigment was found in lakes across this range of TN and conductivity. 


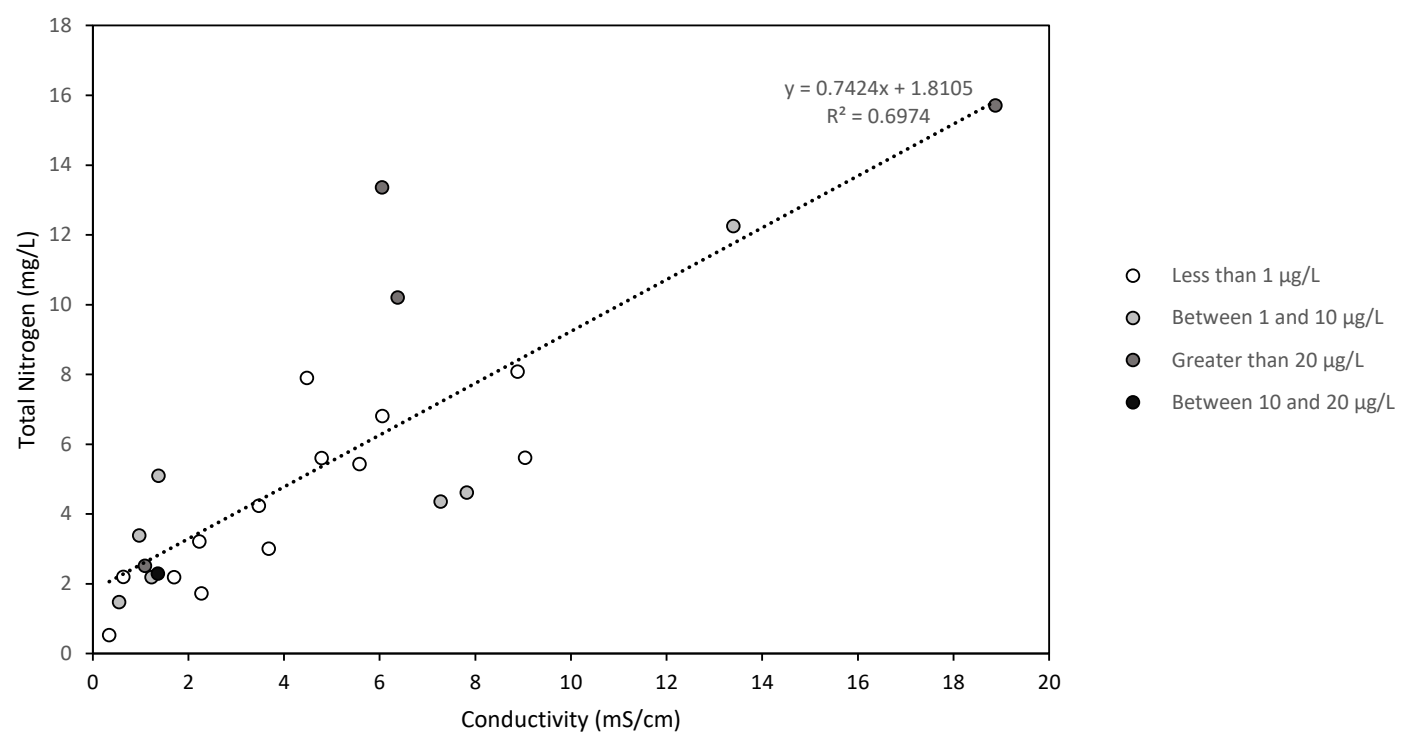

Figure 3 Relationship between total nitrogen $\left(\mathrm{mg} \cdot \mathrm{L}^{-1}\right)$, conductivity $\left(\mathrm{mS} \cdot \mathrm{cm}^{-1}\right)$ and cyanopigment $\left(\mu \mathrm{g} \cdot \mathrm{L}^{-1}\right)$ for 25 shallow prairie lakes sampled in August 2016. Shading illustrates four levels of cyanobacterial pigments $\left(\mu \mathrm{g} \cdot \mathrm{L}^{-1}\right)$. Each point is the mean of three samples taken in the month of August.

Pigment concentrations ranged broadly between and within lakes. Chlorophyll-a ranged from below the detection limit (BDL) to $4,726 \mu \mathrm{g} \cdot \mathrm{L}^{-1}$ (median $6.9 \mathrm{mg} \cdot \mathrm{L}^{-1}$, mean $72.2 \mathrm{mg} \cdot \mathrm{L}^{-1}$ ); 5 samples were BDL. The canthaxanthin pigments ranged from BDL to $783 \mu \mathrm{g} \cdot \mathrm{L}^{-1}$ (mean $7.0 \mu \mathrm{g} \cdot \mathrm{L}^{-1}$ ); 155 samples were BDL. Echinone ranged from BDL to 26.7 (mean $0.74 \mu \mathrm{g} \cdot \mathrm{L}^{-1}$ ); 258 samples were $\mathrm{BDL}$. Myxoxanthophyll ranged from BDL to 429.7 (mean $3.3 \mu \mathrm{g} \cdot \mathrm{L}^{-1}$ ); 232 samples were $\mathrm{BDL}$. The highest cyanobacteria pigment ranged from $\mathrm{BDL}$ to $783.21 \mu \mathrm{g} \cdot \mathrm{L}^{-1}$ (mean $9.1 \mu \mathrm{g} \cdot \mathrm{L}^{-1}$, median $0.3 \mu \mathrm{g} \cdot \mathrm{L}^{-1}$ ); 113 samples were BDL.

Three lakes had low conductivity $\left(<0.800 \mathrm{mS} \cdot \mathrm{cm}^{-1}\right)$, low sulfate and low cyanobacteria biomass (Figure 2). These lakes also had low $\mathrm{N}$ and $\mathrm{P}$, and macrophytes were visually observed during sampling. Another group of lakes between $\sim 1.0-2.0 \mathrm{mS} \cdot \mathrm{cm}^{-1}\left(170-730 \mathrm{mg} \cdot \mathrm{L}^{-1}\right.$ sulfate) consistently had higher cyanobacteria pigment $\left(>1 \mu \mathrm{g} \cdot \mathrm{L}^{-1}\right)$, higher nutrients and higher sulfate. Previous studies have found that sulfate concentrations of $768 \mathrm{mg} \cdot \mathrm{L}^{-1}(8 \mathrm{mM})$ and greater start to inhibit molybdate uptake [54]. Some lakes above $2.0 \mathrm{mS} \cdot \mathrm{cm}^{-1}$ consistently had very low or no cyanobacterial pigments; however a few lakes had mean cyanobacterial pigments between $1-5 \mu \mathrm{g} \cdot \mathrm{L}^{-1}$ and two saline lakes had mean cyanobacterial pigments above $14 \mu \mathrm{g} \cdot \mathrm{L}^{-1}$.

All lakes were relatively small and shallow, except for Crawling Valley, which is a large reservoir with riverine characteristics. The lakes were slightly alkaline $(\mathrm{pH} \mathrm{8.09-10.68)}$ and the water temperature ranged from $11.5-26.0^{\circ} \mathrm{C}$. Turbidity ranged from $1.03-800$ NTU. Although not confirmed in this study, some of the shallow lakes (e.g. Mushroom) have historically been fishless ([34]; Jackson unpublished data, August 2018). Barnett Lake has Brook stickleback (Culaea inconstans), West Lake has Prussian Carp (Carassius gibelio) and presumably East Lake and Long Lake do too, based on their proximity and connecting culverts (Jackson, unpublished data, August 2018). Eagle Lake has (or had) walleye (Sander vitreus), yellow perch (Perca flavescens) and northern 
pike (Esox lucius) [55]. Crawling Valley has been stocked with sport fish. Three species of sucker and two species of minnows have also been caught in the reservoir [55].

\subsection{Patterns of Cyanobacteria Pigments with Sulfate and Molybdenum}

In general, we found higher cyanobacteria pigments (our proxy for biomass) in lakes with TN:TP < 16:1 (Figure 4). Lakes with TN:TP below 16:1 typically also had low sulfate:molybdenum. The first model found that In cyanopigment was significantly correlated to $\ln (T N), \ln (T P)$ in July and September, and $\ln (\mathrm{Mo})$. $\log _{10}\left(\mathrm{SO}_{4}{ }^{2-}\right)$, although not significant $(p=0.055)$, was included in the model.

$$
\begin{gathered}
\ln (\text { cyanopigment }) \sim \ln (t n)+\ln (t p)+\ln (\text { mo })+\log 10(\text { sulfate })+ \\
\ln (t p) * \text { month }+(\text { month } \mid \text { lake })
\end{gathered}
$$
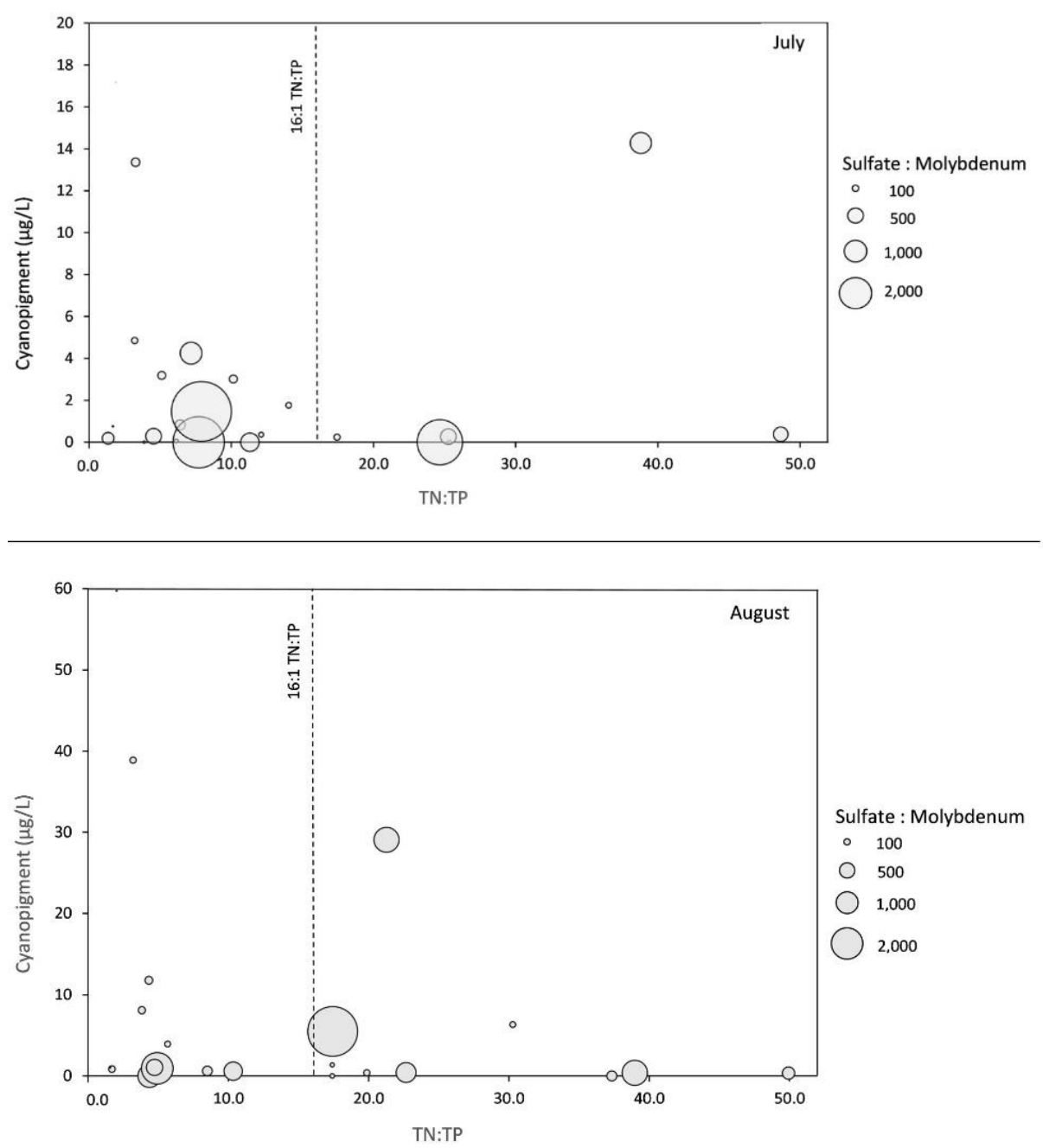

Figure 4 Relationship between cyanobacterial pigments $\left(\mu \mathrm{g} \cdot \mathrm{L}^{-1}\right)$, TN:TP and sulfate to molybdenum in 23 shallow lakes sampled during July and August 2016. The area of the points shows the sulfate to molybdenum ratio as a continuous variable. Each point is the mean of three samples. Two outliers were removed in each figure. In July, (9.2,149, 907) and (147.9, 2.11, 2133); in August (169.8, 0.23, 375) and (322, 711.2, 37); format is (TN:TP, cyanopigment ( $\left.\mu \mathrm{g} \cdot \mathrm{L}^{-1}\right)$, sulfate:molybdenum). 
The linear mixed effects model used 22 lakes; the two lakes with the highest sulfate and one lake with the highest molybdenum (and greatest variability in the sulfate and molybdedum measurements) were removed from this model and only samples with cyanobacteria pigment $>0$ were used $(n=165)$. The model found that $\ln$ (cyanobacteria pigment) was not significantly predicted by $\log _{10}\left(\mathrm{SO}_{4}{ }^{2-}\right)(p=0.055)$, with a negative relationship that had an estimate of $-0.89+/-$ 0.45 (intercept was 1.14 [52]). Although this relationship was not significant at $\alpha=0.05$ using the Satterthwaite method, it was closer, yet still not significant using the chi-square test $(p=0.051)$. There was a significant positive relationship between $\ln$ (cyanobacteria pigments) and $\ln (\mathrm{Mo})(\mathrm{p}=$ $0.005)$, that had an estimate of $0.81+/-0.29$, and a strong, significant relationship between $\ln$ (cyanobacteria pigments) and $\ln (T N)(p=0.005)$, with an estimate of $1.18+/-0.41$ (Supplementary Figure S1). There was also a significant interaction by month between $\ln$ (cyanobacteria pigments) and $\ln (T P)$, with a significant relationship in July $(p=0.0034)$ that had an estimate of $-0.59+/-0.20$ and a significant relationship in September $(p=0.0026)$ with an estimate of $-0.19+/-0.32$ (Supplementary Figure S1). Total phosphorus was not significant in June $(p=0.58)$. The lakes that were removed from Model 1 were Dead Lake $\left(5,811-17,324 \mathrm{mg} \cdot \mathrm{L}^{-1}\right.$ sulfate - mean 11,620 +/1086), Black Lake (2442 - $6482 \mathrm{mg} \cdot \mathrm{L}^{-1} \mathrm{SO}_{4}{ }^{2-}-$ mean $\left.4442+/-453 \mathrm{mg} \cdot \mathrm{L}^{-1}\right)$ and Goat Lake (82.4 $132.5 \mu \mathrm{g} \cdot \mathrm{L}^{-1}$ Mo mean $\left.107+/-15 \mu \mathrm{g} \cdot \mathrm{L}^{-1}\right)$. In Model 1, the interaction terms of $\ln (\mathrm{Mo})$ by month $(\mathrm{p}$ $=0.90), \log _{10}\left(\mathrm{SO}_{4}{ }^{2-}\right)$ by month $(p=0.71), \log _{10}\left(\mathrm{SO}_{4}{ }^{2-}\right)$ by $\ln (\mathrm{Mo})(p=0.55)$, and $\ln (\mathrm{TN})$ by month $(p=$ 0.21 ) were not significant and were therefore removed from the model.

In the second model, $\ln$ (cyanopigment) was significantly predicted by $\ln (T N), \ln (T P)$ by month and $\ln (\mathrm{Mo})$.

$$
\begin{gathered}
\ln (\text { cyanopigment }) \sim \ln (t n)+\ln (t p)+ \\
\ln (\text { mo })+\ln (t p) * \text { month }+(\text { month } \mid \text { lake })
\end{gathered}
$$

To evaluate the effect of removing three lakes in Model 1, all 25 lakes where cyanopigment was above detection limits were included in Model $2(n=186)$. The model was calculated with the same random effect structure as Model 1. $\log _{10}\left(\mathrm{SO}_{4}{ }^{2-}\right)$ became non-significant $(p=0.15)$; however, $\operatorname{In}(\mathrm{TN})$ had a strong effect on $\ln$ (cyanopigment) $(p=0.007$ ) with an estimate of $1.04+/-0.38$ (intercept = 1.19) and $\ln (\mathrm{Mo})$ had an effect on $\ln ($ cyanopigment) $(p=0.047)$ with an estimate of $0.49+/-0.23$ (Supplementary Figure S2; [52]). Ln(TP) in July and September significantly predicted $\operatorname{In}$ (cyanopigment) $(p=0.01, p=0.003)$ with estimates of $-0.47+/-0.18$ and $-0.81+/-0.27$. For Model 2 , the interaction terms of $\ln (\mathrm{Mo})(\mathrm{p}=0.81)$ by month, $\log _{10}\left(\mathrm{SO}_{4}{ }^{2-}\right)$ by $\ln (\mathrm{Mo})(\mathrm{p}=0.41), \log _{10}\left(\mathrm{SO}_{4}{ }^{2-}\right)$ by month $(p=0.29)$, and $\ln (T N)$ by month $(p=0.20)$ were not significant and were removed from the final model.

Model 3 found that cyanopigment presence was significantly predicted by $\ln (T P)$. To account for the dependent variable being truncated in Models 1 and 2, a generalized linear mixed effects model using the binomial distribution to analyze detection and non-detection in cyanobacteria pigment was analyzed to complement the previous two models.

$$
\begin{gathered}
\text { cyanopigment }_{\text {binomial }} \sim \ln (t p)+\text { month }+(1 \mid \text { lake }), \\
\text { family }=\text { binomial }(\text { link }=\operatorname{logit})
\end{gathered}
$$

All lakes and samples were included in the model $(n=300)$, which found In total phosphorus could significantly predict the presence (detection) of cyanobacterial pigments $(p=0.02$ ) with an 
estimate of $0.41+/-0.18$ (intercept was 1.44 [52]). The other fixed effects in Model 1 were tested in this model but were not significant: scaled $\log _{10}$ of sulfate $(p=0.79)$, scaled In molybdenum $(p=$ $54)$ and scaled In total nitrogen $(p=31)$. These terms were removed from the model.

\section{Discussion}

We found a significant positive relationship between cyanobacteria pigment and molybdenum concentration and negative coefficients between cyanobacteria pigment (our proxy for cyanobacteria biomass; [56]) and sulfate concentration. These relationships suggest that increasing sulfate and decreasing molybdenum may limit cyanobacterial growth by out-competing molybdate uptake needed for the Mo-nitrogenase enzyme system responsible for biological N-fixation [57]. Because sulfate and conductivity were strongly correlated in the shallow prairie lakes sampled and regional climate is predicted to become hotter and drier, sulfate will increase in these shallow endorheic lakes and could limit cyanobacterial growth that is projected to increase over the next 30-60 years from anthropogenic eutrophication.

$\mathrm{N}$-fixing cyanobacteria have been shown to dominate low $\mathrm{N}: \mathrm{P}$ lakes through their ability to fix atmospherically derived $\mathrm{N}_{2}$ because other phytoplankton groups cannot $[16,21,22]$. Some, but not all, lakes had higher cyanobacteria growth at low N:P ratios (Figure 4), and the low N:P lakes with the highest cyanobacterial pigments also had low sulfate:molybdenum ratios, which supports the notion that when molybdate availability does not limit Mo-nitrogenase production, cyanobacteria can dominate in low N:P lakes. However, some studies suggest that the total amounts of $\mathrm{N}$ and $\mathrm{P}$ better predict cyanobacterial dominance $[58,59]$. Total nitrogen can be a proxy for phytoplankton biomass, so a strong relationship between cyanobacterial pigment and total nitrogen is not surprising, yet shows that the amount of total nitrogen had the strongest and most consistent correlation to the biomass of the cyanobacterial community. The effect of total phosphorus depended on the month, indicating either a seasonal response to nutrients, or an unmeasured process, such as zooplankton grazing, that affected cyanobacterial biomass. Our results provide correlations between cyanopigment, $\mathrm{SO}_{4}{ }^{2-}$ and $\mathrm{Mo}$ (our estimate of $\mathrm{MoO}_{4}{ }^{2-}$ ); experimental manipulations would be required to confirm causality.

High concentrations of $\mathrm{N}$ and $\mathrm{P}$ come primarily from fertilizers applied to the surrounding cropland [11] although this region also has high geologic $\mathrm{P}$ inputs from glacial till. Most synthetic nitrogen applied to crops is used by the plants, yet isotopic tracing reveals that nitrogen can have long residency times in the soil and that $8-12 \%$ of nitrogen can enter aquatic ecosystems and groundwater [11]. Nitrogen would leave an endorheic shallow lake water column mainly through denitrification and sedimentation; however, inputs tend to exceed losses, so nitrogen and phosphorus concentrations tend to accumulate in shallow lakes. The concentrations of total nitrogen and total phosphorus in the lakes we sampled (Table 1) even exceeded measurements in other shallow lakes in Europe or Asia $[3,60]$, yet the concentrations we measured are similar to previous measurements in these lakes [35]. Most of the lakes range between eutrophic and highly eutrophic and therefore have favourable nutrient conditions for cyanobacterial blooms. However as total nitrogen strongly correlated with conductivity (Figure 3) these highly eutrophic lakes are also more likely to have high sulfate concentrations and provided an opportunity to evaluate the interacting effects of $\mathrm{N}$ and sulfate. 
Cyanobacteria require molybdenum as an essential cofactor for the predominant form of nitrogenase [61]. Microscopy on phytoplankton communities in many of our study lakes over the last 20 years reveals that the same cyanobacterial species appear in summer blooms in these lakes. Microcystis sp. typically appears in late June or July. As summer progresses, the Cyanobacterial community is typically dominated (numerically) by $\mathrm{N}$-fixing species such as Aphanizomenon flosaquae, Oscillatoria sp., Anabaena sp., Nostoc sp., Lyngbya sp., Gleotrichia sp., and Gleocapsa sp.. Blooms of $\mathrm{N}$-fixing capable cyanobacteria suggests that the lakes have transitioned to $\mathrm{N}$-limitation, a hypothesis that could be tested by $\mathrm{N}$ addition to mesocosms. Molybdenum predicted cyanobacterial pigments in both models and through all months, which supported the hypothesis that molybdate is correlated to cyanobacteria biomass. Sulfate competes with molybdate for uptake sites and showed a negative (though non-significant; $p=0.055$ ) relationship with cyanobacterial growth. Although sulfate was not statistically significant in the model, the borderline non-significant statistical result may reveal a biologically significant relationship (additional samples from other lakes would help clarify the generality of this finding). Sulfate would derive from localized areas in the region with high salinity where salts accumulate in groundwater and then pool at the surface in patchy distributions, making some lakes highly saline and other lakes fresh [31]. Nitrogen is also assumed to come from leaching through soil and groundwater, and the combined results of sulfate, molybdenum, $\mathrm{N}$ and $\mathrm{P}$ together show that currently shallow lakes do produce large cyanobacterial blooms, some with associated toxins [52]. Although sulfate can limit cyanobacterial growth, not every lake above $2.0 \mathrm{mS} / \mathrm{cm}\left(\sim 750 \mathrm{mg} \cdot \mathrm{L}^{-1}\right.$ sulfate) had low cyanobacterial biomass, presumably because these lakes are eutrophic and have $\mathrm{N}$ from sources other than the atmosphere (e.g. $\mathrm{NH}_{3}$, urea, dissolved organic nitrogen). Our results are consistent with previous studies that have shown that sulfate and molybdate affect nitrogen fixation in estuaries $[25,62,63]$ where rates of $\mathrm{N}$-fixation are low because molybdenum is scarce due to high sulfate [25].

Seawater is about $29 \mathrm{mM} \mathrm{SO}_{4}{ }^{2-}$ [64] and about $107 \mathrm{nM} \mathrm{Mo} \mathrm{[65],} \mathrm{which} \mathrm{is} \mathrm{approximately} \mathrm{270,000:1}$ $\mathrm{SO}_{4}{ }^{2-}$ :Mo. In the study lakes we calculate an average ratio about one order of magnitude higher at $1.308 \times 10^{6}$ even if we assume Mo has the molecular mass of $\mathrm{MoO}_{4}{ }^{2-}$-because molybdate is the predominant form of Mo. The ratio of $\mathrm{SO}_{4}{ }^{2-}: \mathrm{MoO}_{4}{ }^{2-}$ therefore is higher in these shallow saline lakes than in seawater. Cole [64] suggested that, in marine systems, sulfate would inhibit $\mathrm{MoO}_{4}{ }^{2-}$ uptake at about $5 \%$ seawater concentrations or about $1.45 \mathrm{mM}$ sulfate. Our lakes average (+/- $1 \mathrm{sd}) 17.65$ (20.8) $\mathrm{mM}$ sulfate. If cyanobacteria are similarly affected by sulfate in marine and freshwater systems, sulfate would limit Mo availability in all but four lakes and would be right at limitation in one lake. This could be tested experimentally by adding eg, $\mathrm{Na}_{2} \mathrm{MoO}_{4}$ to lower the $\mathrm{SO}_{4}{ }^{2-}: \mathrm{MoO}_{4}{ }^{2-}$ and measuring the corresponding response of cyanobacteria.

Mo has historically been thought to be essential for $\mathrm{N}_{2}$ fixation [66]; however, recent evidence indicates that some terrestrial $\mathrm{N}$-fixers have $\mathrm{V}$ - and Fe-only nitrogenases [67]. Together with the Mo-nitrogenase, these forms are collectively encoded by a complex system of over 80 [61] Nif genes that produce the necessary gene products for fully functional nitrogenases. In some laboratory growth studies, $\mathrm{N}$-fixation has occurred despite no free $\mathrm{Mo}[68,69]$ and many genes responsible for $\mathrm{V}$ - and Fe-nitrogenases have now been identified [70,71]. Whether or not the same $\mathrm{V}$ - and Fenitrogenase forms identified in soil bacteria exist in freshwater cyanobacteria is not known; however, if they are present and produced they could potentially lead to weaker correlations between $\mathrm{Mo}$ and $\mathrm{N}$-fixing cyanobacteria in aquatic systems and could provide a mechanism for a compensatory response if increasing sulfate effectively makes molybdate less available. 
Furthermore, Fe form and therefore its availability has also been shown to create Fe-limitation in some systems, including saline prairie lakes [72]. In shallow, well-mixed polymictic lakes, such as those we've sampled, $\mathrm{Fe}^{2+}$ released from anoxic sediments would be rapidly oxidized but cyanobacteria do produce siderophones to aid in Fe acquisition [73].

Some of the high TN, TP, chlorophyll- $a$ and cyanopigments we measured would be the result of the worst-case scenario sampling we employed. There would be different values of TN and TP from an integrated sample taken at various depths because of patchiness in the algal biomass in some lakes. The measurements would also be affected by variation in annual phytoplankton phenologyspring (2016) was about 3 weeks earlier than 'normal' with about three times higher precipitation in July 2016 (142 mm) than the monthly average for July (49 mm from 2004-2015) [74]. Even though the September sampling was at the very beginning of the month, most of the cyanobacterial blooms seen in July and August were not visible by September. The lakes were located within $100 \mathrm{~km}$ of each other and should share regional climate and geology. The models we ran indicate that even when interactions between independent variables are included, the bivariate relationships remain significant. Furthermore, the removal of outliers from the data in Model 1 did not lead to different results when compared to Model 2.

\subsection{Thresholds and Alternate Stable States in the Lakes}

Shallow lakes and aquatic ecosystems are among the most altered ecosystems on the planet [75] and continually respond to anthropogenic nutrient loading. Nutrient inputs can shift lakes from a clear, low-nutrient, high-macrophyte state to a turbid, high-nutrient, high-phytoplankton state, the latter often containing cyanobacteria [34, 76-78]. We did not identify statistical thresholds that would suggest bimodality in the relationships between sulfate or molybdenum and cyanobacteria and therefore the relationships between sulfate, molybdenum, N, P and cyanobacteria are continuous in the lakes and year we sampled.

Despite lack of evidence of nutrient-cyanobacteria thresholds, the lakes can still be grouped into three categories. In the two lakes with low nutrients, low salinity and low cyanobacterial biomass (Figure 2) we also noted high macrophyte abundance and low turbidity. A second group of lakes had higher nutrients, were more turbid and had more cyanobacteria biomass, and while they had increased conductivity, it was below $2.0 \mathrm{~ms} / \mathrm{cm}$, which is near the threshold of molybdate uptake inhibition of $768 \mathrm{mg} \cdot \mathrm{L}^{-1}$ sulfate found by Marino et al. [54] and also a rough distinction between fresh and brackish water. The third group of lakes had conductivity above $2.0 \mathrm{mS} / \mathrm{cm}$ and also had increasing sulfate, increasing turbidity and less cyanobacteria biomass. However, this last group of lakes also had the highest $\mathrm{N}$ (Figure 3). There were two lakes above this threshold where cyanobacteria bloomed above $14 \mu \mathrm{g} \cdot \mathrm{L}^{-1}$, showing that this threshold did not entirely limit cyanobacterial growth. One of these lakes (Dog, which had extreme blooms) may have an unidentified nutrient source while the other lake (Bow) has abundant Microcystis sp., which does not fix $\mathrm{N}$. Other brackish lakes had cyanobacteria pigment between 1-5 $\mu \mathrm{g} \cdot \mathrm{L}^{-1}$ periodically through the season. Cyanobacterial growth in brackish lakes shows that other conditions can override sulfate inhibition; for example, high $\mathrm{N}$ concentrations can support cyanobacteria growth that does not require $\mathrm{N}$-fixation.

Most of the lakes we studied appear to be in a turbid state. A level of $\sim 4$ NTU has been identified in these shallow lakes as a threshold between clear and turbid states [34]. Three lakes were 
consistently below this level, while 22 lakes had values higher than this threshold. This strongly suggests that the majority of saline lakes in this region are turbid lakes with high nutrients and higher phytoplankton growth. An increase in turbidity leads to a decline in macrophytes as lakes become more eutrophied [79]; a survey in Europe showed that macrophytes did not grow above $2.5 \mathrm{mg} / \mathrm{L}$ of TN (Jeppesen et al. 2007). This turbidity has implications for management because clear lakes are typically more desirable, and are associated with higher water quality. Turbid lakes can also be challenging for management because shallow lakes tend to resist returning to a clear state even when nutrient levels are reduced [80], or nutrient levels need to be reduced lower than the level that tipped the lake into the turbid state originally. Furthermore, turbid lakes might exist as either intermediate turbidity, mixed-assemblage phytoplankton communities or high turbidity, cyanobacteria-dominated communities [80]. Cyanobacterial blooms can also produce microcystins, which pose additional challenges for drinking water, recreational use, watering livestock and management.

Zooplankton help to stabilize clear lakes by grazing phytoplankton; however, zooplankton have historically been thought to be unable to handle large colonial cyanobacteria and lack critical nutrients from grazing cyanobacteria [81-83]. More recent research suggests that zooplankton can graze large filamentous and colonial cyanobacteria [84] and that successive generations of zooplankton living in a cyanobacteria-dominated lake could co-exist with, but not control, increased cyanobacterial blooms [85]. With increasing salinity, the species richness in the zooplankton community may decrease, however, if salinity increases to a level where fish cannot survive, zooplankton may positively respond to a lack of predators [86]. We did not measure zooplankton abundance, yet their grazing could affect our results because it would reduce the phytoplankton biomass and specifically cyanobacteria biomass we measured, which of course would affect relationships with other variables. This unmeasured factor could also affect the significance of interaction terms by month because the zooplankton populations' predation pressure may rise and fall over the summer months, as evidenced by zooplankton-related phenomena such as the spring clear-water phase [87].

\section{Conclusions}

The negative relationship between sulfate and cyanobacteria biomass in our space-for-time analysis suggests that as prairie lakes become more saline, even with increased nutrients, cyanobacteria biomass will decrease. Climate change is predicted to increase annual mean temperatures across the prairies by $3-5^{\circ} \mathrm{C}$ and reduce precipitation by $5-10 \%$ by the 2050 s [9]. While warm temperatures can favour cyanobacterial growth [88], warm temperatures can decrease water levels in evaporation basins, increase sulfate concentrations and potentially limit cyanobacteria growth. Knowledge gained from this space-for-time analysis suggests that increasing sulfate affects cyanobacteria growth, although not all lakes with high sulfate will have low cyanobacteria.

\section{Acknowledgments}

We thank Andrea Scott for help with the molybdenum analyses, Jose Luis Rodriguez Gil for help with the pigment analysis and Lawrence Harder and Samuel Robinson for advice with the statistical analyses. The authors have no conflict of interest to declare. 


\section{Author Contributions}

SMJ performed field sampling, laboratory measurements, data curation, statistical analyses, wrote the first manuscript draft and reviewed and edited the final draft. LJ conceived of the idea, provided resources and supervision, and reviewed and edited the final draft.

\section{Funding}

This study was supported by the Natural Sciences and Engineering Research Council of Canada through a Discovery Grant to LJ and through the Alberta Conservation Association Grants in Biodiversity to SMJ.

\section{Competing Interests}

The authors have declared that no competing interests exist.

\section{Additional Materials}

The following additional materials are uploaded at the page of this paper.

1. Figure S1: Partial effects for model 1, with residuals, showing significant relationships between In cyanopigment and (a) total nitrogen, (b) total phosphorus by month, (c) sulfate and (d) molybdenum. The model analyzed 165 samples from 25 shallow prairie lakes sampled in 2016 . The two lakes with the highest sulfate and lake with the highest molybdenum were removed. Observations where cyanopigment were below detection limits were not included.

2. Figure S2: Partial effects for model 2, with residuals, showing significant relationships between In cyanopigment and (a) total nitrogen, (b) total phosphorus by month and (c) molybdenum. The model analyzed 186 samples from 25 shallow prairie lakes sampled in 2016. Observations where cyanopigment was below detection limits were not included.

\section{References}

1. Chorus I, Welker M. Toxic cyanobacteria in water. 2nd ed. Boca Raton: CRC Press; 2021.

2. Codd G, Lindsay J, Young F, Morrison L, Metcalf J. Harmful cyanobacteria: From mass mortalities to management measures. In: Harmful cyanobacteria. Dordrecht: Springer; 2005.

3. Wu SK, Xie P, Liang GD, Wang SB, Liang XM. Relationships between microcystins and environmental parameters in 30 subtropical shallow lakes along the Yangtze River, China. Freshw Biol. 2006; 51: 2309-2319.

4. Kosten S, Huszar VL, Bécares E, Costa LS, van Donk E, Hansson LA, et al. Warmer climates boost cyanobacterial dominance in shallow lakes. Glob Chang Biol. 2012; 18: 118-126.

5. Sinang SC, Reichwaldt ES, Ghadouani A. Spatial and temporal variability in the relationship between cyanobacterial biomass and microcystins. Environ Monit Assess. 2013; 185: 63796395.

6. Taranu ZE, Gregory-Eaves I, Leavitt PR, Bunting L, Buchaca T, Catalan J, et al. Acceleration of cyanobacterial dominance in north temperate-subarctic lakes during the Anthropocene. Ecol Lett. 2015; 18: 375-384. 
7. Evans JC, Prepas EE. Potential effects of climate change on ion chemistry and phytoplankton communities in prairie saline lakes. Limnol Oceanogr. 1996; 41: 1063-1076.

8. Pierrehumbert RT. Climate change and the tropical Pacific: The sleeping dragon wakes. Proc Natl Acad Sci USA. 2000; 97: 1355-1358.

9. Barrow E, Yu G. Climate scenarios for Alberta. Prairie adaptation research collaborative. Regina: Prairie Adaptation Research Collaborative; 2005; No. 06-02.

10. Williams WD. Environmental threats to salt lakes and the likely status of inland saline ecosystems in 2025. Environ Conserv. 2002; 29: 154-167.

11. Sebilo M, Mayer B, Nicolardot B, Pinay G, Mariotti A. Long-term fate of nitrate fertilizer in agricultural soils. Proc Natl Acad Sci USA. 2013; 110: 18185-18189.

12. Maheaux $H$, Leavitt PR, Jackson LJ. Asynchronous onset of eutrophication among shallow prairie lakes of the northern Great Plains, Alberta, Canada. Glob Chang Biol. 2016; 22: 271-283.

13. Chorus I, Bartram J. Toxic cyanobacteria in water: A guide to their public health consequences, monitoring and management. London: Routledge; 1999.

14. O'Neil JM, Davis TW, Burford MA, Gobler CJ. The rise of harmful cyanobacteria blooms: The potential roles of eutrophication and climate change. Harmful Algae. 2012; 14: 313-334.

15. Marino R, Howarth RW, Shamess J, Prepas E. Molybdenum and sulfate as controls on the abundance of nitrogen-fixing cyanobacteria in saline lakes in Alberta. Limnol Oceanogr. 1990; 35: 245-259.

16. Schindler DW, Hecky RE, Findlay DL, Stainton MP, Parker BR, Paterson MJ, et al. Eutrophication of lakes cannot be controlled by reducing nitrogen input: Results of a 37-year whole-ecosystem experiment. Proc Natl Acad Sci USA. 2008; 105: 11254-11258.

17. Schindler DW, Carpenter SR, Chapra SC, Hecky RE, Orihel DM. Reducing phosphorus to curb lake eutrophication is a success. Environ Sci Technol. 2016; 50: 8923-8929.

18. Rabalais NN. Nitrogen in aquatic ecosystems. Ambio. 2002; 31: 102-112.

19. Cotner JB. Nitrogen is not a 'House of Cards'. Environ Sci Technol. 2017; 51: 3.

20. Schindler DW. Evolution of phosphorus limitation in lakes: Natural mechanisms compensate for deficiencies of nitrogen and carbon in eutrophied lakes. Science. 1977; 195: 260-262.

21. Higgins SN, Paterson MJ, Hecky RE, Schindler DW, Venkiteswaran JJ, Findlay DL. Biological nitrogen fixation prevents the response of a eutrophic lake to reduced loading of nitrogen: Evidence from a 46-year whole-lake experiment. Ecosystems. 2018; 21: 1088-1100.

22. Tilman D, Kilham SS, Kilham P. Phytoplankton community ecology: The role of limiting nutrients. Annu Rev Ecol Evol Syst. 1982; 13: 349-372.

23. Vitousek PM, Howarth RW. Nitrogen limitation on land and in the sea: how can it occur? Biogeochemistry. 1991; 13: 87-115.

24. Moore CM, Mills MM, Arrigo KR, Berman-Frank I, Bopp L, Boyd PW, et al. Processes and patterns of oceanic nutrient limitation. Nat Geosci. 2013; 6: 701-710.

25. Howarth RW, Cole JJ. Molybdenum availability, nitrogen limitation, and phytoplankton growth in natural waters. Science. 1985; 229: 653-655.

26. Cole JJ, Lane JM, Marino R, Howarth RW. Molybdenum assimilation by cyanobacteria and phytoplankton in freshwater and salt water. Limnol Oceanogr. 1993; 38: 25-35.

27. Dumont HJ. The biological cycle of molybdenum in relation to primary production and waterbloom formation in a eutrophic pond: With 3 figures and 1 table in the text. Internationale Vereinigung für theoretische und angewandte Limnologie: Verhandlungen. 1972; 18: 84-92. 
28. Pizarro J, Rubio MA, Ríos E, Vila I. Concentration level of molybdenum in aquatic systems. Fresenius Environ Bull. 2014; 23: 159-168.

29. Marino R, Howarth RW. Why is planktonic nitrogen fixation so rare in coastal marine ecosystems? Insights from a cross-systems approach. In: Aquatic microbial ecology and biogeochemistry: A dual perspective. Cham: Springer; 2016. pp.127-139.

30. Natural Regions Committee. Natural Regions and Subregions of Alberta. Compiled by D.J. Downing and W.W. Pettapiece. Edmonton: Government of Alberta; 2006; No. T/852.

31. Kwiatkowski J, Marciak LC, Wentz D, King CR. Salinity mapping for resource management within the County of Wheatland, Alberta. Edmonton: Conservation and Development Branch, Alberta Agriculture Food and Rural Development; 1995.

32. Alberta Government. Alberta government regional dashboard [Internet]. Edmonton: Government of Alberta; 2016 [cited date 2018 August 22th]. Available from: https://regionaldashboard.alberta.ca/\#/.

33. Alberta Agriculture and Rural Development. 2011 census of agriculture for Alberta: I.D., M.D., and county data by land-use region [Internet]. Edmonton: Government of Alberta; 2014. Available from: https://open.alberta.ca/dataset/ba0ebb70-ec2f-4e45-86588d835928f0a7/resource/3e938800-c725-4162-a39e-d260a461b19d/download/66524262014-2011-census-agriculture-alberta.pdf.

34. Jackson LJ. Macrophyte-dominated and turbid states of shallow lakes: Evidence from Alberta lakes. Ecosystems. 2003; 6: 213-223.

35. Maheux HM. Trends and drivers of water clarity in shallow, prairie lakes of southern Alberta. Calgary: University of Calgary; 2012.

36. SmartChem. Ammonia in water, waste water and soil extracts and other aqueous samples. Unity Scientific; 2011.

37. Strickland JD, Parsons TR. A practical handbook of seawater analysis. Ottawa: Fisheries Research Board of Canada; 1968.

38. SmartChem. Phosphorus, all forms, orthophosphate, hydrolyzable, and total in water, waste water and soil extracts and other aqueous samples. Unity Scientific; 2011.

39. SmartChem. Sulfate in water, waste water and soil extracts and other aqueous samples. Unity Scientific; 2011.

40. Mackey MD, Mackey DJ, Higgins HW, Wright SW. CHEMTAX-a program for estimating class abundances from chemical markers: Application to HPLC measurements of phytoplankton. Mar Ecol Prog Ser. 1996; 144: 265-283.

41. Tamm M, Freiberg R, Tõnno I, Nõges P, Nõges T. Pigment-based chemotaxonomy-a quick alternative to determine algal assemblages in large shallow eutrophic lake? PloS One. 2015; 10 : e0122526.

42. Roy S, Llewellyn CA, Egeland ES, Johnsen G. Phytoplankton pigments: Characterization, chemotaxonomy and applications in oceanography. Cambridge: Cambridge University Press; 2011.

43. R Core Team. R: A language and environment for statistical computing [Internet]. Vienna: $\mathrm{R}$ Foundation for Statistical Computing; 2016. Available from: https://www.R-project.org/.

44. RStudio Team. RStudio: Integrated Development for R. Boston: RStudio, Inc.; 2016.

45. Douglas B, Maechler M, Bolker B, Walker S. Fitting linear mixed-effects models using Ime4. J Stat Softw. 2015; 67: 1-48. 
46. Kuznetsova A, Brockhoff PB, Christensen RH. ImerTest package: Tests in linear mixed effects models. J Stat Softw. 2017; 82: 1-26.

47. Fox J. Effect displays in R for generalised linear models. J Stat Softw. 2003; 8: 1-27.

48. McCullagh P. Generalized linear models. Eur J Oper Res. 1984; 16: 285-292.

49. Wickham H. ggplot2: Elegant graphics for data analysis. Basel: Springer; 2009.

50. Kahle DJ, Wickham H. ggmap: Spatial visualization with ggplot2. R J. 2013; 5: 144-161.

51. Bolker BM. Linear and generalized linear mixed models. In: Ecological statistics: Contemporary theory and application. Oxford: Oxford University Press; 2015. pp.309-333.

52. Anderson SM. Toxic cyanobacteria in relation to sulfate, molybdenum, nitrogen and phosphorus in Alberta's shallow prairie lakes. Calgary: University of Calgary; 2018.

53. Vollenweider RA, Kerekes J. Eutrophication of waters. Monitoring, assessment and control. Paris: Organisation for Economic Co-operation and Development; 1982.

54. Marino R, Howarth RW, Chan F, Cole JJ, Likens GE. Sulfate inhibition of molybdenum-dependent nitrogen fixation by planktonic cyanobacteria under sea water conditions: A non-reversible effect. In: Aquatic biodiversity. Dordrecht: Springer; 2003. pp.277-293.

55. Mitchell P, Prepas EE. Atlas of Alberta lakes. Edmonton: University of Alberta Press; 1990.

56. Kasinak JM, Holt BM, Chislock MF, Wilson AE. Benchtop fluorometry of phycocyanin as a rapid approach for estimating cyanobacterial biovolume. J Plankton Res. 2015; 37: 248-257.

57. Bulen WA, LeComte JR. The nitrogenase system from Azotobacter: Two-enzyme requirement for $\mathrm{N}_{2}$ reduction, ATP-dependent $\mathrm{H}_{2}$ evolution, and ATP hydrolysis. Proc Natl Acad Sci USA. 1966; 56: 979-986.

58. Pick FR, Lean DR. The role of macronutrients $(C, N, P)$ in controlling cyanobacterial dominance in temperate lakes. N Z J Mar Freshwater Res. 1987; 21: 425-434.

59. Downing JA, Watson SB, McCauley E. Predicting cyanobacteria dominance in lakes. Can J Fish Aquat Sci. 2001; 58: 1905-1908.

60. Jeppesen E, Søndergaard M, Meerhoff M, Lauridsen TL, Jensen JP. Shallow lake restoration by nutrient loading reduction-some recent findings and challenges ahead. In: Shallow lakes in a changing world. Dordrecht: Springer; 2007. pp.239-252.

61. Mus F, Alleman AB, Pence N, Seefeldt LC, Peters JW. Exploring the alternatives of biological nitrogen fixation. Metallomics. 2018; 10: 523-538.

62. Howarth RW, Marino R, Cole JJ. Nitrogen fixation in freshwater, estuarine, and marine ecosystems. 2. Biogeochemical controls. Limnol Oceanogr. 1988; 33: 688-701.

63. Howarth RW, Marino R, Lane J, Cole JJ. Nitrogen fixation in freshwater, estuarine, and marine ecosystems. 1. Rates and importance 1. Limnol Oceanogr. 1988; 33: 669-687.

64. Cole JJ, Howarth RW, Nolan SS, Marino R. Sulfate inhibition of molybdate assimilation by planktonic algae and bacteria: Some implications for the aquatic nitrogen cycle. Biogeochemistry. 1986; 2: 179-196.

65. Glass JB, Axler RP, Chandra S, Goldman CR. Molybdenum limitation of microbial nitrogen assimilation in aquatic ecosystems and pure cultures. Front Microbiol. 2012; 3: 331.

66. Joerger RD, Bishop PE, Evans HJ. Bacterial alternative nitrogen fixation systems. Crit Rev Microbiol. 1988; 16: 1-14.

67. Harris DF, Lukoyanov DA, Kallas H, Trncik C, Yang ZY, Compton P, et al. Mo-, V-, and Fenitrogenases use a universal eight-electron reductive-elimination mechanism to achieve $\mathrm{N}_{2}$ reduction. Biochemistry. 2019; 58: 3293-3301. 
68. Chisnell JR, Premakumar R, Bishop PE. Purification of a second alternative nitrogenase from a nifHDK deletion strain of Azotobacter vinelandii. J Bacteriol. 1988; 170: 27-33.

69. Riddle GD, Simonson JG, Hales BJ, Braymer HD. Nitrogen fixation system of tungsten-resistant mutants of Azotobacter vinelandii. J Bacteriol. 1982; 152: 72-80.

70. Rubio LM, Ludden PW. Maturation of nitrogenase: A biochemical puzzle. J Bacteriol. 2005; 187: 405-414.

71. Seefeldt LC, Hoffman BM, Dean DR. Mechanism of Mo-dependent nitrogenase. Annu Rev Biochem. 2009; 78: 701-722.

72. Evans JC, Prepas EE. Relative importance of iron and molybdenum in restricting phytoplankton biomass in high phosphorus saline lakes. Limnol Oceanogr. 1997; 42: 461-472.

73. Molot LA, Watson SB, Creed IF, Trick CG, McCabe SK, Verschoor MJ, et al. A novel model for cyanobacteria bloom formation: The critical role of anoxia and ferrous iron. Freshw Biol. 2014; 59: 1323-1340.

74. Environment Canada. Weather and climate historical data [Internet]. Quebec: Environment Canada; 2021 [cited date 2018 August 24th]. Available from:

http://climate.weather.gc.ca/historical data/search historic data e.html.

75. Carpenter SR, Stanley EH, Vander Zanden MJ. State of the world's freshwater ecosystems: Physical, chemical, and biological changes. Annu Rev Environ Resour. 2011; 36: 75-99.

76. Scheffer M, Hosper SH, Meijer ML, Moss B, Jeppesen E. Alternative equilibria in shallow lakes. Trends Ecol Evol. 1993; 8: 275-279.

77. Körner S. Development of submerged macrophytes in shallow Lake Müggelsee (Berlin, Germany) before and after its switch to the phytoplankton-dominated state. Arch Hydrobiol. 2001; 152: 395-409.

78. Scheffer M, Carpenter SR. Catastrophic regime shifts in ecosystems: Linking theory to observation. Trends Ecol Evol. 2003; 18: 648-656.

79. Phillips G, Willby N, Moss B. Submerged macrophyte decline in shallow lakes: What have we learnt in the last forty years? Aquat Bot. 2016; 135: 37-45.

80. Scheffer M, Rinaldi S, Gragnani A, Mur LR, van Nes EH. On the dominance of filamentous cyanobacteria in shallow, turbid lakes. Ecology. 1997; 78: 272-282.

81. Arnold DE. Ingestion, assimilation, survival, and reproduction by daphnia pulex fed seven species of blue-green algae. Limnol Oceanogr. 1971; 16: 906-920.

82. Lampert W. Laboratory studies on zooplankton-cyanobacteria interactions. N Z J Mar Freshwater Res. 1987; 21: 483-490.

83. Havens K, East T, Beaver J. Experimental studies of zooplankton-phytoplankton-nutrient interactions in a large subtropical lake (Lake Okeechobee, Florida, USA). Freshw Biol. 1996; 36: 579-597.

84. Work KA, Havens KE. Zooplankton grazing on bacteria and cyanobacteria in a eutrophic lake. J Plankton Res. 2003; 25: 1301-1306.

85. Ger KA, Hansson LA, Lürling M. Understanding cyanobacteria-zooplankton interactions in a more eutrophic world. Freshw Biol. 2014; 59: 1783-1798.

86. Gutierrez MF, Tavşanoğlu ÜN, Vidal N, Yu J, Teixeira-de Mello F, Çakiroglu Al, et al. Salinity shapes zooplankton communities and functional diversity and has complex effects on size structure in lakes. Hydrobiologia. 2018; 813: 237-255. 
87. Lampert W, Fleckner W, Rai H, Taylor BE. Phytoplankton control by grazing zooplankton: A study on the spring clear-water phase 1. Limnol Oceanogr. 1986; 31: 478-490.

88. Paerl HW, Huisman J. Blooms like it hot. Science. 2008; 320: 57-58.

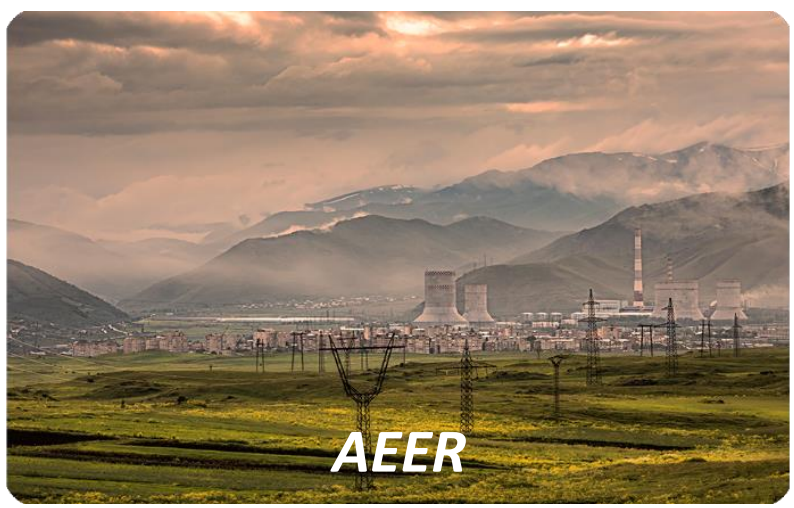

Enjoy $A E E R$ by:

1. Submitting a manuscript

2. Joining in volunteer reviewer bank

3. Joining Editorial Board

4. Guest editing a special issue

For more details, please visit:

http://www.lidsen.com/journals/aeer 